3. ACR Lung-RADS - Update 1.1; 2019. Available at: https://www.acr.org/-/media/ ACR/Files/RADS/Lung-RADS/LungRADS-1-1-updates.pdf. Accessed November $10,2020$.

4. Evron JM, Reyes-Gastelum D, Banerjee M, Scherer LD, Wallner LP, Hamilton AS, et al. Role of patient maximizing-minimizing preferences in thyroid cancer surveillance. J Clin Oncol. 2019:37:3042-9.

5. Bauml JM, Troxel A, Epperson CN, Cohen RB, Schmitz K, Stricker C, et al. Scanassociated distress in lung cancer: quantifying the impact of "scanxiety" Lung Cancer. 2016:100:110-3.
6. Howlader N, Forjaz G, Mooradian MJ, Meza R, Kong CY, Cronin KA, et al. The effect of advances in lung-cancer treatment on population mortality. $N$ Engl J Med. 2020;383:640-9.

7. Antonia SJ, Villegas A, Daniel D, Vicente D, Murakami S, Hui R, et al. Durvalumab after chemoradiotherapy in stage III non-small-cell lung cancer. $N$ Engl J Med. 2017;377:1919-29.

8. Wu YL, Tsuboi M, He J, John T, Grohe C, Majem M, et al. Osimertinib in resected EGFR-mutated non-small-cell lung cancer. N Engl J Med. 2020;383: $1711-23$.
See Article page 680.

\section{Commentary: The value of close surveillance after lung cancer surgery: How absence of evidence is not evidence of absence}

\author{
Abbas E. Abbas, MD
}

As "the other pandemic," lung cancer kills more humans worldwide than the other 3 leading cancers combined (breast, colorectal, and prostate). ${ }^{1}$ Survival remains dismal, except in early stages when surgical resection is the standard of care, offering a 5-year survival up to $94 \%$ for stage I disease. ${ }^{2}$ After surgery, however, there are inherent risks of cancer recurrence, either the recurrent initial pulmonary cancer (RIPLC) or a new primary lung cancer (NPLC).

A retrospective study in 2013 described the results of computed tomography (CT) surveillance of 1294 patients who underwent lung cancer resection between 2004 and 2009. On follow-up, $27 \%$ redeveloped malignancy (RIPLC in $20 \%$ and NPLC in 7\%). The risk of RIPLC was $6 \%$ to $10 \%$ per person year the first 4 years after surgery but

From the Division of Thoracic Surgery, Department of Thoracic Medicine and Surgery, Temple University Hospital and Fox Chase Comprehensive Cancer Center, Philadelphia, $\mathrm{Pa}$.

Disclosures: The author reported no conflicts of interest.

The Journal policy requires editors and reviewers to disclose conflicts of interest and to decline handling or reviewing manuscripts for which they may have a conflict of interest. The editors and reviewers of this article have no conflicts of interest.

Received for publication Nov 20, 2020; revisions received Nov 20, 2020; accepted for publication Nov 23, 2020; available ahead of print Dec 3, 2020.

Address for reprints: Abbas E. Abbas, MD, Department of Thoracic Medicine and Surgery, Temple University Hospital and Fox Chase Comprehensive Cancer Center, Lewis Katz School of Medicine, 3401 N Broad St, Suite C-500, Philadelphia, PA 19035 (E-mail: abbas.abbas@temple.edu).

J Thorac Cardiovasc Surg 2021;162:686-7

0022-5223/\$36.00

Copyright $₫ 2020$ Published by Elsevier Inc. on behalf of The American Association for Thoracic Surgery

https://doi.org/10.1016/j.jtcvs.2020.11.124
Check for updates

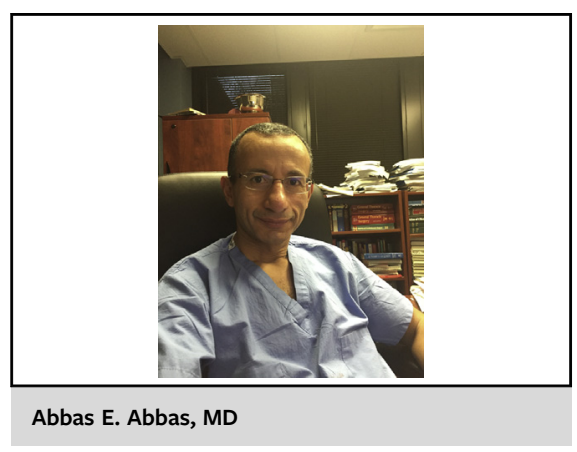

CENTRAL MESSAGE

After surgical resection of lung cancer, there is a risk of recurrence of the initial tumor or development of a new primary cancer. Despite absent evidence of benefit from frequent surveillance, there may be value in treating recurrent cancer earlier.

decreased to $2 \%$ thereafter. The risk of NPLC was $3 \%$ to $6 \%$ per person year and remained constant over time. ${ }^{3}$ In another study, 20,032 patients in the SEER database who survived at least 5 years after lung resection had a 10-year risk of NPLC of $8.36 \%$. $^{4}$ To put this risk of recurrence in perspective, the number of lobectomies or pneumonectomies performed for lung cancer in 2012 in the United States was $86,700 .^{5}$ By extrapolation, the expected number of RIPLCs $(20 \%)$ is approximately 17,000 and that of NPLC (7\%-8\%) is approximately 7000 patients.

Notwithstanding this known risk of redeveloping cancer, few studies have shown any significant benefit from postresection imaging surveillance (PRIS). A meta-analysis in 
2011 of 9 comparative studies including 1669 patients, comparing clinical follow-up with scheduled PRIS, showed nonsignificant improved survival in the PRIS group. ${ }^{6}$ However, others showed no improvement in overall or diseasefree survival from scheduled PRIS compared with simple clinical or even absent follow-up. ${ }^{7}$ Likewise, no difference in outcome has been detected on the basis of frequency ${ }^{8,9}$ or modality (positron emission tomography, CT, or x-ray) of PRIS. ${ }^{10,11}$ Despite this, most professional societies recommend CT scan surveillance every 3 to 6 months for the first few years after resection followed by annual studies in perpetuity. These recommendations undoubtedly stem at least in part from lessons learned in lung cancer screening studies. However, it is important to note that surveillance is significantly different from screening. The National Lung Cancer Screening Trial was designed to look for positive findings of new primaries, for example, nodules that are noncalcified, that are greater than $4 \mathrm{~mm}$, that are enlarging in size, or that have changes in attenuation. It did not specifically look for signs of recurrence of lung cancer, which usually include regional adenopathy and distant metastasis. ${ }^{12}$

Heiden and colleagues ${ }^{13}$ presented a comprehensive treatise on the current guidelines for PRIS, reviewing the evidence or lack thereof behind them. The article determines that the current recommendations of scanning every 3 to 6 months may be too aggressive and suggests that a more "balanced" protocol of once a year may be sufficient. The article justifies this approach by the lack of effective therapy for most regional or distant recurrences and the lack of proof of any benefit from frequent surveillance. $^{13}$

Regional or distant RIPLC carries a grim prognosis, but there are more therapeutic options today than even a decade ago, including targeted therapy, immunotherapy, hypofractionated radiation, and catheter-based ablation. This makes it difficult to justify intentionally avoiding its early identification by less frequent scanning. It is also difficult to know whether delayed treatment of RIPLC may lead to shorter survival. Obviously, the additional benefit of early diagnosis of NPLC is undeniable. As we have learned from the NLST, CT scanning saves lives in individuals who meet high-risk criteria. Of course, no one is at a higher risk of lung cancer than a patient who has already had one.
Finally, attempting to conduct a long-term randomized study comparing different surveillance modalities and frequencies on a large number of participants and for a long enough period to show a statistical difference is unlikely to ever be attempted or funded. Therefore, although there may be absence of evidence for the value of close PRIS, most physicians instinctively know that this does not mean evidence of absence.

\section{References}

1. Global Cancer Facts \& Figures | American Cancer Society. Available at: https:// www.cancer.org/research/cancer-facts-statistics/global.html. Accessed November 15,2020

2. Abbas AE. Commentary: robotic anatomic lung resection: raising the bar of our expectations in treating lung cancer. J Thorac Cardiovasc Surg. 2020;159: 689-90.

3. Lou F, Huang J, Sima CS, Dycoco J, Rusch V, Bach PB. Patterns of recurrence and second primary lung cancer in early-stage lung cancer survivors followed with routine computed tomography surveillance. J Thorac Cardiovasc Surg. 2013;145:75-82.

4. Han SS, Rivera GA, Tammemägi MC, Plevritis SK, Gomez SL, Cheng I, et al. Risk stratification for second primary lung cancer. J Clin Oncol. 2017;35:2893-9.

5. Fingar KR, Stocks C, Weiss AJ, Steiner CA. Most frequent operating room procedures performed in U.S. hospitals, 2003-2012: Statistical Brief \#186. In Healthcare Cost and Utilization Project (HCUP) Statistical Briefs. Agency for Healthcare Research and Quality (US); 2006. Available at: http://www.ncbi nlm.nih.gov/books/NBK274246/. Accessed November 15, 2020.

6. Calman L, Beaver K, Hind D, Lorigan P, Roberts C, Lloyd-Jones M. Survival benefits from follow-up of patients with lung cancer: a systematic review and meta-analysis. J Thorac Oncol. 2011:6:1993-2004.

7. Wong ML, McMurry TL, Stukenborg GJ, Francescatti AB, Amato-Martz C, Schumacher JR, et al. Impact of age and comorbidity on treatment of nonsmall cell lung cancer recurrence following complete resection: a nationally representative cohort study. Lung Cancer Amst Neth. 2016;102:108-17.

8. Subramanian M, Liu J, Greenberg C, Schumacher J, Chang GJ, McMurry TL, et al. Imaging surveillance for surgically resected stage I non-small cell lung cancer: is more always better? J Thorac Cardiovasc Surg. 2019;157:1205-17.e2.

9. McMurry TL, Stukenborg GJ, Kessler LG, Colditz GA, Wong ML, Francescatti AB, et al. More frequent surveillance following lung cancer resection is not associated with improved survival: a nationally representative cohort study. Ann Surg. 2018;268:632-9.

10. Crabtree TD, Puri V, Chen SB, Gierada DS, Bell JM, Broderick S, et al. Does the method of radiologic surveillance affect survival after resection of stage I nonsmall cell lung cancer? J Thorac Cardiovasc Surg. 2015;149:45-52, 53.e1-3.

11. Takenaka D, Ohno Y, Koyama H, Nogami M, Onishi Y, Matsumoto K, et al. Integrated FDG-PET/CT vs. standard radiological examinations: comparison of capability for assessment of postoperative recurrence in non-small cell lung cancer patients. Eur J Radiol. 2010;74:458-64.

12. National Lung Screening Trial Research Team, Aberle DR, Berg CD, Black WC, Church TR, Fagerstrom RM, et al. The national lung Screening trial: overview and study design. Radiology. 2011;258:243-53.

13. Heiden BT, Subramanian MP, Puri V, Kozower BD. Striking a balance: surveillance of non-small cell lung cancer after resection. J Thorac Cardiovasc Surg. $2021 ; 162: 680-4$ 